\title{
ZONASI ANOMALI UNSUR NICKEL DI WEDA, KABUPATEN HALMAHERA TENGAH, MALUKU UTARA BERDASARKAN DATA UNIVARIAT DAN MULTIVARIAT
}

\author{
Ahmad Fadhly ${ }^{1}$, Dian Hadiyansyah ${ }^{2}$ \\ ${ }^{1,2}$ Prodi Teknik Pertambangan, Sekolah Tinggi Teknologi Industri Padang \\ Email : ahmadfadhly.geo08@yahoo.com
}

\begin{abstract}
Abstrak: Daerah yang diteliti ini terletak di Daerah Weda, Kabupaten Halmahera Tengah, yang dimana merupakan jalur mineralisasi logam yang termasuk ke dalam Halmahera magmatic arc, dan mempunyai cakupan wilayah $10 \mathrm{~km}$ x $15 \mathrm{~km}$. Tujuan dari penelitian ini adalah untuk mengungkapkan keterdapatan kandungan unsur logam $\mathrm{Ni}$ pada endapan sungai dalam bentuk peta kandungan unsur logam tersebut. Identifikasi kandungan unsur logam dari contoh yang diambil dilakukan di laboratorium geokimia PSMBP menggunakan metoda Atomotic Absorbtion Spectrometri Logametri (AAS). Sebanyak 12 unsur secara garis besar telah dilakukan analisis kadarnya di dalam percontohan sedimen sungai dengan kadar yang tertinggi dan diolah untuk mendapatkan zona anomalinya. Hal ini mennggunakan software SPSS 21.0 dipakai sebagai penentuan anomali berdasarkan nilai korelasi antar unsur, maka di daerah penelitian terdapat dua unsur yang memiliki nilai yang sama sesuai dengan data statistik univariat, multivariat dengan uji analisis faktor. Kedua asosiasi hubungan unsur tersebut adalah : $\mathrm{Ni}, \mathrm{Co}, \mathrm{Li}, \mathrm{K}, \mathrm{Cr}$, pembentukan faktor 1 memperlihatkan adanya hubungan yang kuat antara $\mathrm{Ni}$ serta asosiasi $\mathrm{Co}, \mathrm{Li}, \mathrm{K}$ dan $\mathrm{Cr}$ yang dihubungkan dengan kondisi geologi regional dikawasan penelitian, yaitu didominasi oleh batuan beku basa dan ultrabasa. Potensi mineral di daerah yang diteliti ini adalah minerali nikel laterit. Mineral yang terjadi dalam batuan ultrabasa ditunjukkan adanya mineral garnierit seperti yang ditemukan si sebelah utara Lelilef, Wasia dan di Yonelo daerah Weda Utara dan tanda-tanda lateritisasi terhadap batuan ultrabasa.
\end{abstract}

Kata Kunci: nikel, mineral, metoda Atomotic Absorbtion Spektrokopi Logam (AAS), Nikel.

\begin{abstract}
The area is located in the Vedic region, central Halmahera Regency, which is the path of metal mineralization which belongs to the Halmahera magmatic arc, and has a coverage area of $10 \mathrm{~km} \times 15 \mathrm{~km}$. The purpose of this research is to Reveal the contents of the metal element Ni on river deposits in the form of the content map of the metal element. Identifying the content of metal elements from examples taken in the PSMBP geochemical laboratory using the Atomotic Absorbtion spectrometry Logametri (AAS) method. A total of 12 elements have been conducted in the level analysis in the river sedimentary pilot with the highest rate and processed to obtain its anomaltic zones. This uses SPSS 21.0 software used as a determination of anomalies based on the correlation value between elements, then in the research area there are two elements that have the same value according to statistical data univariate, multivariate with analysis test Factors. Both associations of the elements are: 1) Ni, Co, $\mathrm{Li}, \mathrm{K}, \mathrm{Cr}$, forming factor 1 shows a strong relationship between $\mathrm{Ni}$ and association $\mathrm{Co}, \mathrm{Li}, \mathrm{K}$ and $\mathrm{Cr}$ are linked to regional geological conditions in the area of research, namely dominated By base frozen rocks and Ultrabasa. The mineral potential in this researched area is Minerali nickel Laterit. The minerals that occur in the Ultrabasa are shown in the presence of garnierit minerals such as those found in the north of Lelilef, Wasia and in the Yonelo Northern Vedic region and the Lateritisasi signs of the Ultrabasa.
\end{abstract}

Keywords: nikel, mineral, method Atomotic Absorbtion Spectrometri Logametri (AAS), Nikel 


\section{PENDAHULUAN}

Daerah yang akan diteliti termasuk bagian mandala geologi Halmahera yang merupakan bagian tengah jalur mineral logam yang termasuk dalam Busur Halmahera, secara regional telah dilakukan banyak penyelidikan dan eksplorasi khususnya untuk mineral. Secara administratif termasuk pada wilayah Daerah Weda, Kabupaten Halmahera Tengah dan sebagian Kabupaten Halmahera Selatan, Provinsi Maluku Utara. Mandala Geologi Halmahera Tengah terutama dibentuk oleh satuan batuan ultrabasa yang sebarannya cukup luas. Batuan sedimen berumur Kapur (Kd) dan berumur Paleosen-Eosen (Tped, Tpec dan Tpel) diendapkan tidak selaras di atas batuan ultrabasa.

Dengan peranan potensi sumber daya alam daerah Weda, Kabupaten Halmahera Tengah yang besar dalam kehidupan masyarakat khususnya di bidang mineral, dan umumnya pada bidang pertanian, perkebunan, peternakan, pemukiman maka banyak perusahaan yang melirik dalam berinvestasi untuk industri sumber daya alam . Hal ini menuntut kebutuhan akan penelitian penelitian yang berkompeten dan metodemetode pembelajaran yang dipakai atau diterapkan berkaitan dengan bidang sumber daya alam khususnya di bidang geologi.. Sehubungan dengan hal itu, maka penulis mencoba melakukan studi tentang penerapan suatu metode di bidang geologi berupa data geokimia unsur. Berkembangnya aplikasi kimia dalam kegiatan eksplorasi terutama metode stream sediment menjadi salah satu alternatif untuk identifikasi daerah mineral bijih.

\section{METODOLOGI}

Metode penelitian yang dilakukan terdiri dari beberapa metode; meliputi pengumpulan data sekunder berupa geologi dan mineralisasi logam, pengumpulan data primer berupa data kegiatan lapangan, analisis laboratorium untuk mengolah data lapangan dan data geokimia. Tahap pendahuluan sebelum melakukan penelitian dan pengambilan data lapangan, meliputi studi regional daerah penelitian untuk mengetahui gambaran umum tentang data geologi daerah penelitian, sehingga kegiatan lapangan sangat membantu dalam mendukung kompilasi data sekunder sebagai dasar utama dalam penelitian.

Dalam pelaksanaan survei geokimia ini penulis mengacu pada Peta Geologi Regional Lembar Ternate skala $1: 250.000$, yang diterbitkan oleh PPPG, tahun 1980. Peta dasar yang digunakan untuk orientasi lapangan adalah Peta Rupa Bumi Indonesia skala 1 : 50.000 yang diterbitkan oleh lembaga pemerintah yang bertanggung jawab dalam bidang geospasial. Selanjutnya peta pola aliran sungai skala $1: 50.000$ didijitasi dan digunakan untuk pembuatan peta rencana pengambilan contoh survei geokimia skala 1 : 250.000 yang mengacu pada sistem georeferensi WGS 84 .

\section{HASIL DAN PEMBAHASAN}

\section{HASIL}

\section{Pengambilan Contoh Endapan Sungai Aktif dan Pengamatan Geologi}

Pembahasan tentang daerah penelitian di Halmahera Bagian Tengah, Maluku Utara meliputi geologi, geokimia dan lokasi potensi dan tipe mineralisasi logam. Kondisi geologi dapat memberikan gambaran akan peluang terbentuknya mineralisasi logam, terutama berkaitan dengan litologi dan struktur geologi. Sedangkan geokimia akan memberikan gambaran nilai sebaran unsur pada daerah penelitian, dalam hal ini daerah anomali dapat mengindikasikan adanya cebakan mineral logam. Integrasi layer data geologi dan geokimia akan memberikan 
gambaran lebih akurat tentang daerah potensi mineralisasi logam.

Penelitan pemetaan geokimia ini, bertujuan untuk mengetahui anomali sebaran unsurunsur Ni. Pengambilan contoh endapan sungai aktif dilakukan pada sungai - sungai pada orde 2 dan 3 (Lampiran Peta 1). Pengambilan data geologi berupa data batuan yang tersingkap sebagai pendukung hasil analisis geokimia. Contoh yang diambil adalah berupa material yang berhubungan langsung dengan sungai aktif yang didulang dengan ukuran messh 40\# dan 80\# yang kemungkinan bisa menarik unsur-unsur logam terdulang secara acak (random) pada mesh tersebut yang terbawa oleh arus sungai dari sumbernya.

Dalam penelitian ini jumlah conto yang terkumpul masing-masing sebanyak 137 conto sedimen sungai, 87 conto konsentrat dulang dan 12 contoh batuan. Conto-conto tersebut setelah diseleksi dan dikeringkan untuk mendapatkan contoh yang representatif dan contoh - contoh tersebut dikirim ke laboratorium kimia dan fisika mineral untuk dianalisis.

\section{Contoh Endapan Sungai Stasiun SS 17/HT/364}

Conto endapan sungai ini diambil di daerah Weda berasal dari sungai Ake Fidi, sumber dari percabangan anak-anak sungai intermiten Ake Goro. Karakteristik morfografi pada daerah ini dicirikan oleh bentuk lahan perbukitan bergelombang dengan ketinggian 50-550 mdpl dan sungaisungai membentuk pola rektangular. Lokasi pengambilan conto endapan sungai berada di areal perkebunan dan hutan

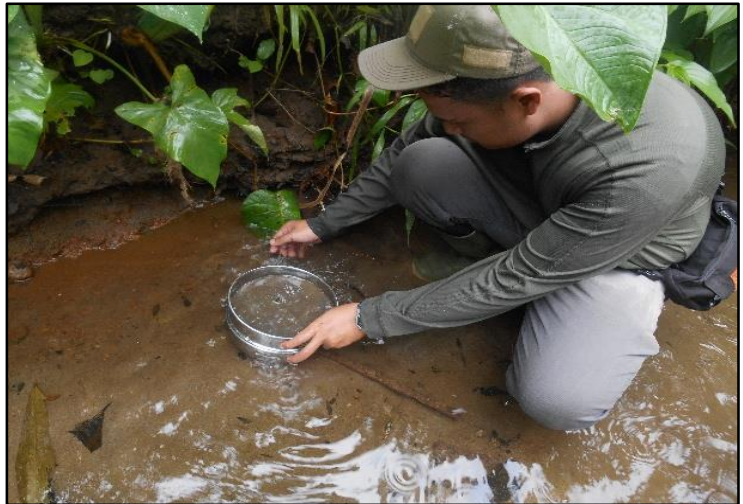

Gambar 1. Pengambilan contoh sedimen sungai menggunakan saringan 80 \#
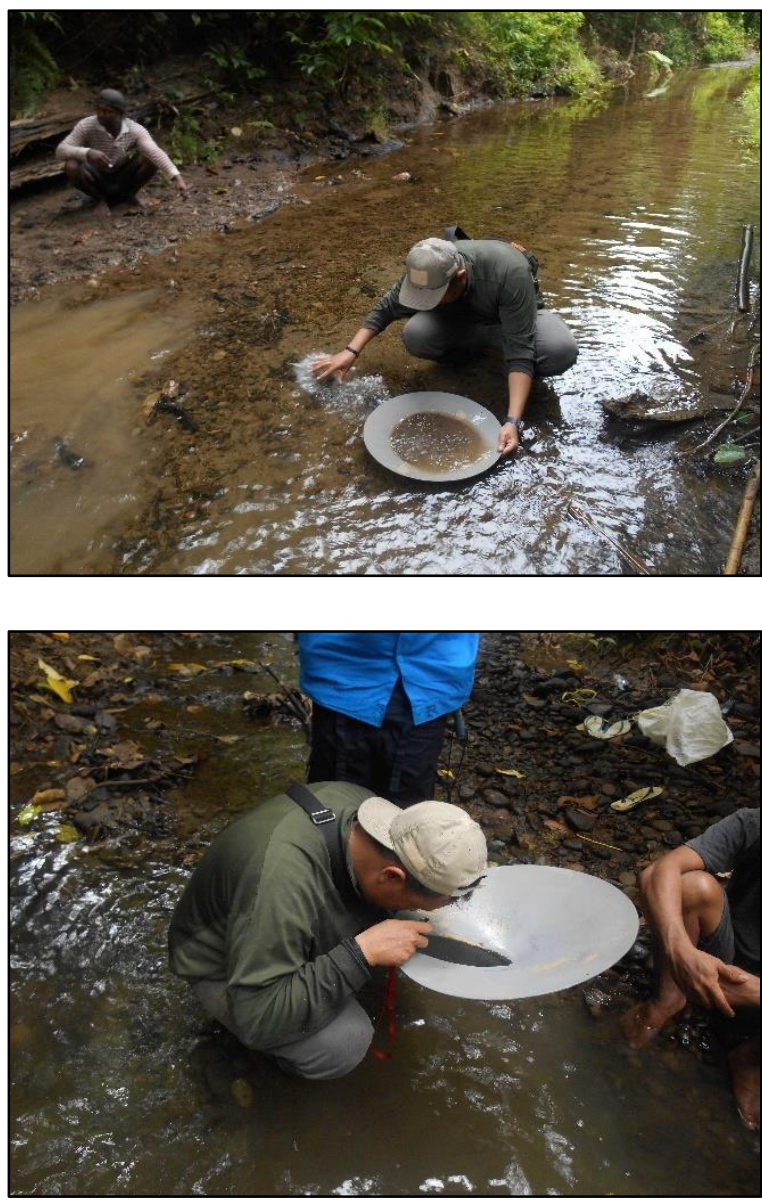

Gambar 2. Pendulangan dan pengamatan mineral berat 


\section{Contoh Endapan Sungai Stasiun SS 17/HT/279}

Contoh endapan sungai ini diambil di daerah Kobe dan sekitar desa Sepo dari sungai Ake Walwalebesbisele. Karakteristik morfografi pada daerah ini merupakan bentuk lahan Perbukitan Terjal dengan ketinggian 2501250 mdpl dan sungai-sungai membentuk pola trelis dikontrol oleh struktur. Lokasi pengambilan contoh endapan sungai berada cukup jauh dari pemukiman dan berada di areal Hutan Lindung.

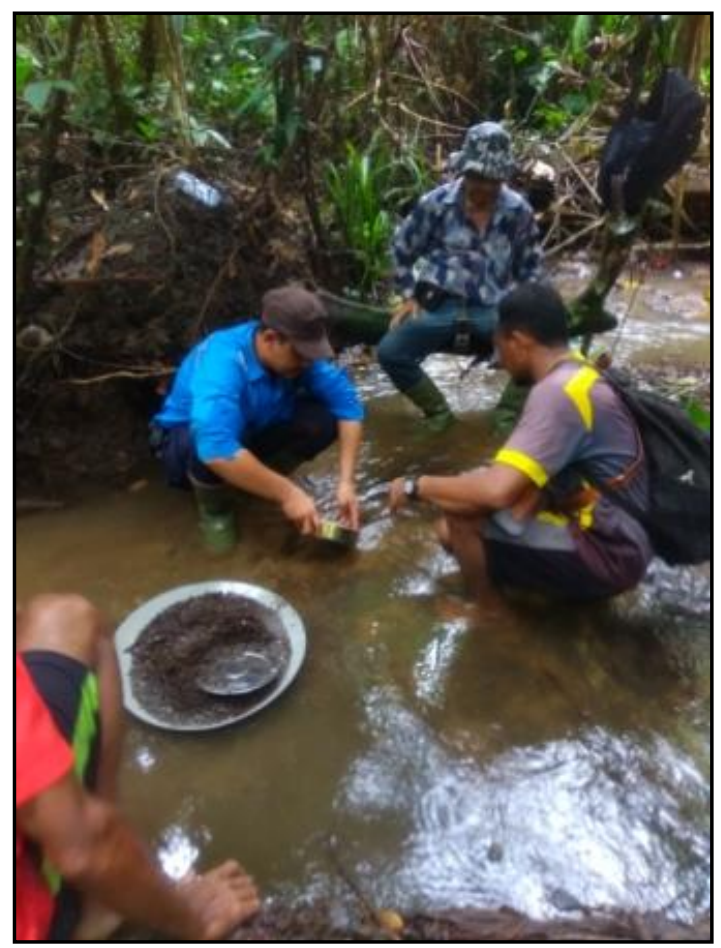

Gambar 3. Pengambilan contoh geokimia sedimen sungai menggunakan saringan 80 \#

Pada pengambilan contoh endapan sungai juga dilakukan pengamatan geologi di sekeliling sungai, yang tersusun oleh batuan beku ultrabasa yang mendominasi litologi daerah ini. Secara megaskopis, warna segar abu-abu kehijauan, hipokristalin, porfiritik faneritik, keras, struktur massif. satuan batuan ini tersebar di bagian tengah - utara daerah penyelidikan yang menempati daerah morfologi perbukitan terjal. Pada umumnya batuan ini tersingkap pada lereng-lereng sungai di bagian hulu yang berlereng terjal, seperti yang tersingkap di hulu Ake Welwalebesbisele pada lokasi 17/HT/0279A (Gambar 4), sedangkan yang tersingkap di hulu Ake Meno dekat dengan lokasi 17/HT/0286 CD terlihat menunjukkan gejala pelapukan dan oksidasi, (Gambar 6). Satuan batuan ini secara regional dapat dikorelasikan dengan Kompleks Batuan Ultrabasa berumur Pra Kapur (T. Apandi dkk, 1980). Pengamatan float batuan di lingkungan batuan ultrabasa menunjukan adanya indikasi berupa kehadiran mineral garnierit dalam float, seperti yang ditemukan di hilir Ake Welwalebesbisele dan Ake Wosia (Gambar 5).

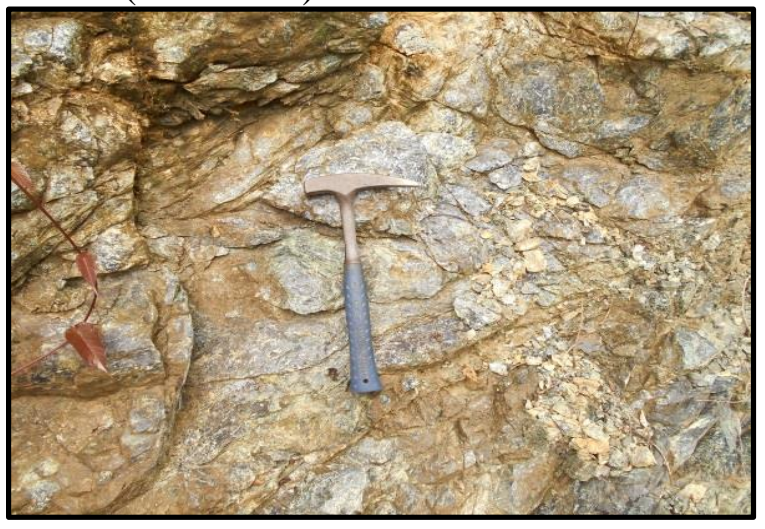

Gambar 4. Singkapan batuan serpentinit di hulu Ake Wel wale besbi sele (17/HT/0279AR) 


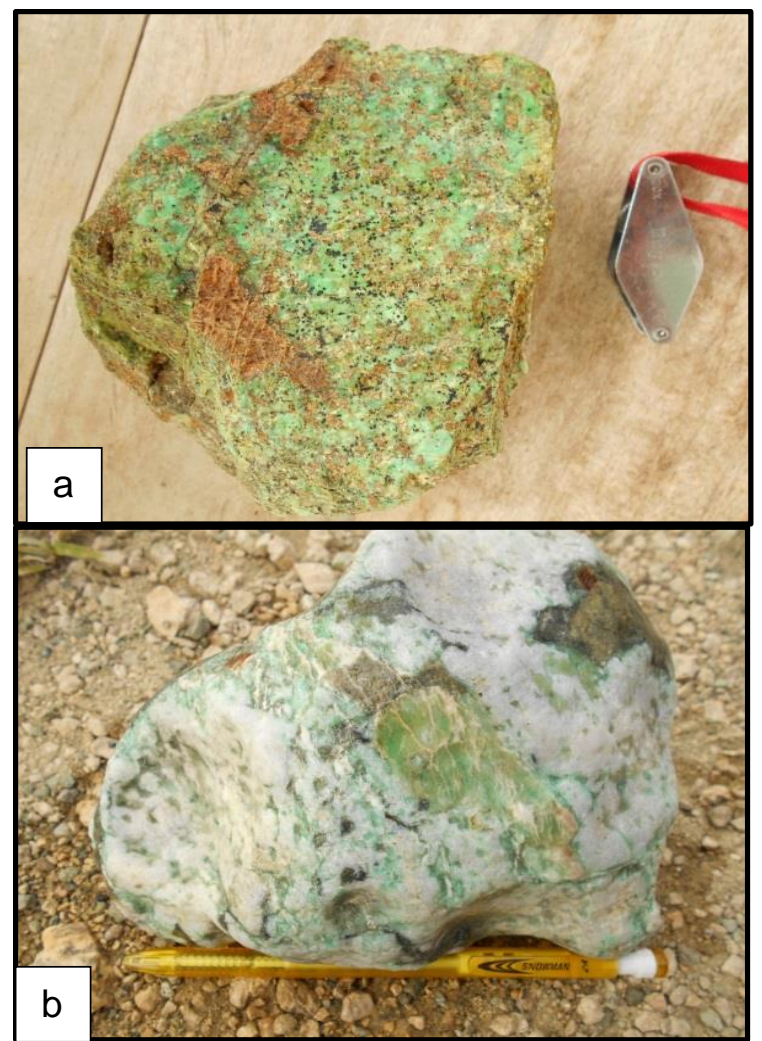

Gambar 5. Float batuan mengandung mineral garnierit di Ake Welwalebesbisele (a) dan Ake Wosia (b)

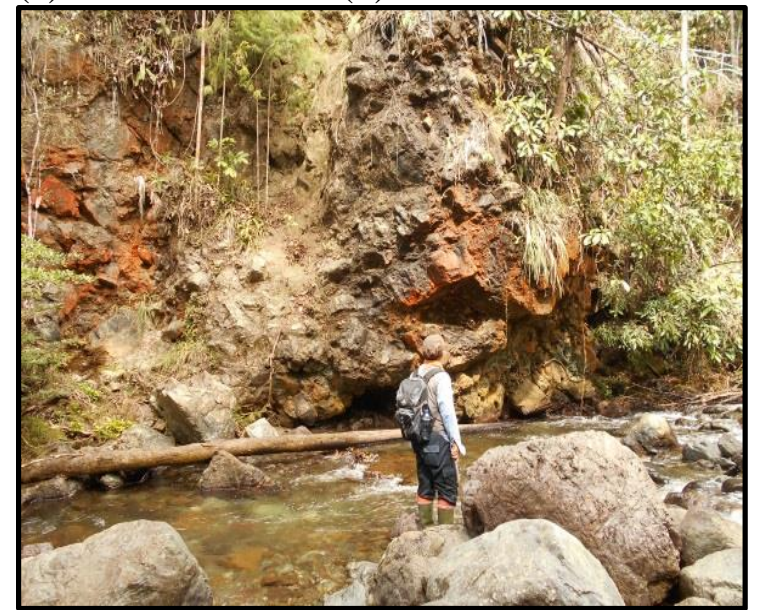

Gambar 6. Singkapan batuan ultrabasa menunjukkan oksidasi pelapukan di hulu Ake Ake Meno.

\section{PEMBAHASAN}

\section{Penyebaran dan Kandungan Unsur Ni}

Penentuan kelas geokimia unsur $\mathrm{Cu}, \mathrm{Pb}, \mathrm{Zn}$, $\mathrm{Co}, \mathrm{Ni}, \mathrm{Mn}, \mathrm{Ag}, \mathrm{Li}, \mathrm{K}, \mathrm{Fe}, \mathrm{Cr}$ dan Au dilakukan untuk mengetahui pola sebaran anomali unsur. Pola sebaran tersebut dapat dipakai sebagai petunjuk adanya mineralisasi logam. Peta sebaran unsur sesuai kelas geokimia dapat dilihat pada Gambar Lampiran 1. Upaya membandingkan kesamaan ciri geokimia dan geologi daerah penelitian ini dilakukan dengan cara pemodelan menggunakan sistem informasi geografis dan statistik. Analisis unsur yang terdapat pada sampel geokimia endapan sungai aktif dilakukan terhadap 12 unsur, sebagai target untuk ditentukan daerah potensi mineralisasi logam dasar. Ringkasan statistik geokimia endapan sungai aktif dapat dilihat pada (Tabel 1) Penentuan kelas geokimia untuk mendapatkan daerah anomali nilai kandungan unsur menurut Rose dkk. (1979) dalam Ghazali dkk. (1986) menggunakan cara manual sehingga diperoleh ringkasan 4 kelas interval unsur dengan rumus (Tabel 2)

- Kelas 1 : Rata-rata + 1 nilai simpangan baku

- Kelas 2 : Rata-rata + 1,5 nilai simpangan baku

- Kelas 3 : Rata-rata + 2 nilai simpangan baku

- Kelas 4 : Rata-rata + 2,5 nilai simpangan baku

Tabel 1. Ringkasan statistik geokimia contoh endapan sungai aktif Di Kawasan Weda, Halmahera Tengah, Provinsi Maluku Utara.

\begin{tabular}{|c|c|c|c|c|c|c|c|c|}
\hline Unsur & $\begin{array}{c}\text { Rata- } \\
\text { rata }\end{array}$ & $\begin{array}{c}\text { Standar } \\
\text { Deviasi }\end{array}$ & $\begin{array}{c}\text { Jumlah } \\
\text { Analisis }\end{array}$ & Minimal & Maximal & $\begin{array}{c}\text { Rata-Rata } \\
\text { Pada } \\
\text { kerak Bumi } \\
\text { (Rose, 1979), } \\
\text { (Berkman, } \\
\text { 2001). }\end{array}$ & $\begin{array}{c}\text { Nomor } \\
\text { Atom }\end{array}$ & $\begin{array}{c}\text { Berat } \\
\text { Atom }\end{array}$ \\
\hline $\mathrm{Cu}$ & 31,31 & 13,45 & 137 & 7 & 72 & 5 & 29 & 63,54 \\
\hline $\mathrm{Pb}$ & 44,98 & 11,83 & 137 & 15 & 95 & 12 & 82 & 207,19 \\
\hline $\mathrm{Zn}$ & 115,00 & 63,62 & 137 & 21 & 349 & 130 & 30 & 65,37 \\
\hline $\mathrm{Co}$ & 94,80 & 90,01 & 137 & 26 & 739 & 10 & 27 & 58,933 \\
\hline $\mathrm{Ni}$ & 1289,05 & 1597,26 & 137 & 27 & 9600 & & & \\
\hline $\mathrm{Mn}$ & 1651,90 & 777,63 & 137 & 0 & 4953 & & 25 & 54,938 \\
\hline $\mathrm{Ag}$ & 3,13 & 0,75 & 137 & 1,50 & 5,60 & 0,09 & 47 & 107,87 \\
\hline $\mathrm{Li}$ & 8,28 & 4,57 & 137 & 1 & 24 & 25 & 3 & 6,939 \\
\hline $\mathrm{K}$ & 3011,04 & 2550,15 & 137 & 0 & 9684 & 850 & 19 & 39,102 \\
\hline $\mathrm{Fe}$ & 10,23 & 5,84 & 137 & 0,68 & 33,64 & 5,8 & 26 & 55,847 \\
\hline $\mathrm{Cr}$ & 745,78 & 795,36 & 137 & 35 & 4875 & 20 & 24 & 51,996 \\
\hline $\mathrm{Au}$ & 2,23 & 3,39 & 137 & 0 & 26 & & 79 & 196,97 \\
\hline
\end{tabular}




\section{Analisis Unsur Tunggal (Univariat Analysis)}

Analisis univariat diartikan sebagai pengolahan data setiap unsur secara sendirisendiri. Dalam hal ini tidak dilakukan pengamatan hubungan antara satu unsur dengan unsur yang lainnya. Berdasarkan hasil penelitian di lapangan, dilakukan analisis 12 unsur tunggal yang berasal dari sampel geokimia sedimen sungai aktif.

Tabel 2. Ringkasan kelas interval conto endapan sungai aktif Halmahera Bagian Tengah, Maluku utara.

\begin{tabular}{|c|c|c|c|c|}
\hline \multirow{2}{*}{ Unsur } & \multicolumn{4}{|c|}{ Kelas Interval } \\
\cline { 2 - 5 } & 1 & 2 & 3 & 4 \\
\hline $\mathrm{Cu}$ & $<44,77$ & $44,77-51,49$ & $51,5-58,22$ & $58,23-72$ \\
\hline $\mathrm{Pb}$ & $<56,81$ & $56,81-62,73$ & $62,74-68,64$ & $68,65-95$ \\
\hline $\mathrm{Zn}$ & $<178,62$ & $178,62-210,43$ & $210,44-242,24$ & $242,25-349$ \\
\hline $\mathrm{Co}$ & $<184,81$ & $184,81-229,81$ & $229,82-274,82$ & $274,83-739$ \\
\hline $\mathrm{Ni}$ & $<4395,79$ & $4395,79-5850,99$ & $5851-7306,18$ & $7306,19-2986$ \\
\hline $\mathrm{Mn}$ & $<2429,53$ & $2429,53-2818,35$ & $2818,36-3207,17$ & $3207,18-499$ \\
\hline $\mathrm{Ag}$ & $<3,88$ & $3,88-4,25$ & $4,26-4,63$ & $4,64-5,6$ \\
\hline $\mathrm{Li}$ & $<12,86$ & $12,86-15,15$ & $15,16-17,43$ & $17,44-24$ \\
\hline $\mathrm{K}$ & $<5561,2$ & $5561,2-6836,28$ & $6836,29-8111,35$ & $8111,36-968$ \\
\hline $\mathrm{Fe}$ & $<16,06$ & $16,06-18,98$ & $18,99-21,9$ & $21,91-33,64$ \\
\hline $\mathrm{Cr}$ & $<1541,14$ & $1541,14-1938,82$ & $1938,83-2336,5$ & $2336,51-487$ \\
\hline $\mathrm{Au}$ & $<5,63$ & $5,63-7,32$ & $7,33-9,02$ & $9,03-26$ \\
\hline
\end{tabular}

Bahasan tentang 4 kelas interval (Tabel 2) adalah sebagai berikut:

\section{Sebaran Unsur Nikel (Ni)}

Terdapat dua kandungan unsur $\mathrm{Ni}$ yang tinggi yakni yang melebihi nilai rata-rata + 2,5 SB atau tepatnya dalam interval 319,82 - 739 yaitu kandungan Ni 29800 ppm pada titik lokasi 17/HT/0335/F2 dan kandungan Ni 9600 ppm pada titik lokasi 17/HT/0279/D.

\section{Analisis Unsur Jamak (Multivariate Analysis)}

Analisis kekerabatan unsur (multivariate) merupakan analisis yang memperkuat hasil analisis univariat terutama dalam menentukan bagaimana keterdapatan akumulasi unsur pada suatu daerah. Analisis ini bertujuan mencari bagaimana hubungan atau kekerabatan unsur yang mungkin terjadi pada suatu proses mineralisasi (Ghazali dkk, 1986. Analisis unsur jamak dilakukan dengan metode analisis faktor dan menggunakan perangkat statistik yaitu IBM SPSS 21.0 yang terintegrasi dengan perangkat ARCGIS yang dapat menghasilkan peta hubungan antar unsur di wilayah penelitian.

Dari hasil analisis faktor diperoleh hasil uji Bartlett test of Sphericity dan dari uji MSA diketahui nilai KMO-MSA mengalami peningkatan setelah dikeluarkannya $\mathrm{Pb}$ dan Au. Nilai tersebut menjadi 0,684 dari sebelumnya 0,649 dan masih melebihi 0,500 sehingga dinyatakan memenuhi syarat (Tabel 3). Demikian pula nilai-p untuk uji Bartlett adalah sebesar 4,1×10-144 yang sangat jauh lebih kecil dari 0,05 sehingga korelasi antar variabel dinyatakan sangat mencukupi dan memenuhi syarat untuk dapat dilakukannya analisis faktor.

Thel Hasil Uji Asumsi MSA Parsial Setiap Unsu
\begin{tabular}{|c|c|c|}
\hline Unsur & MSA & Keterangan \\
\hline $\mathrm{Cu}$ & 0,876 & Memenuhi Syarat \\
\hline $\mathrm{Pb}$ & 0,440 & $\begin{array}{c}\text { Tidak Memenuhi } \\
\text { Syarat }\end{array}$ \\
\hline $\mathrm{Zn}$ & 0,549 & Memenuhi Syarat \\
\hline $\mathrm{Co}$ & 0,557 & Memenuhi Syarat \\
\hline $\mathrm{Ni}$ & 0,840 & Memenuhi Syarat \\
\hline $\mathrm{Mn}$ & 0,703 & Memenuhi Syarat \\
\hline $\mathrm{Ag}$ & 0,761 & Memenuhi Syarat \\
\hline $\mathrm{Li}$ & 0,679 & Memenuhi Syarat \\
\hline $\mathrm{K}$ & 0,680 & Memenuhi Syarat \\
\hline $\mathrm{Fe}$ & 0,584 & Memenuhi Syarat \\
\hline $\mathrm{Cr}$ & 0,716 & Memenuhi Syarat \\
\hline $\mathrm{Au}$ & 0,383 & $\begin{array}{c}\text { Tidak Memenuhi } \\
\text { Syarat }\end{array}$ \\
\hline
\end{tabular}




\section{Pembentukan Banyaknya Faktor Pengganti}

Fungsi dari analisis faktor adalah melakukan reduksi atau pengurangan jumlah variabel menjadi beberapa faktor pengganti yang lebih sedikit jumlahnya, namun mampu menyerap informasi yang optimal. Dalam hal ini analisis faktor bertujuan untuk mengelompokkan unsur-unsur yang memiliki kekerabatan dalam satu kelompok yang baru. Penentuan banyaknya kelompok atau faktor pengganti dilakukan dengan kriteria Eigen Value, dalamhal ini banyaknya faktor pengganti ditentukan dari Eigen Value yang lebih dari

Tabel 4. Eigen Value dan Total Variance Explainde

\begin{tabular}{|l|r|r|r|}
\multicolumn{4}{|c|}{ Total Variance Explained } \\
\cline { 2 - 4 } Component & \multicolumn{3}{|c|}{ Initial Eigenvalues } \\
\cline { 2 - 4 } & \multicolumn{1}{|c|}{ Total } & \% of Variance & Cumulative \% \\
\hline $\mathbf{1}$ & $\mathbf{3 , 3 9 1}$ & $\mathbf{3 3 , 9 1 1}$ & $\mathbf{3 3 , 9 1 1}$ \\
$\mathbf{2}$ & $\mathbf{2 , 8 9 9}$ & $\mathbf{2 8 , 9 9 5}$ & $\mathbf{6 2 , 9 0 6}$ \\
4 &, 905 & 9,054 & 71,960 \\
5 &, 758 & 7,576 & 79,536 \\
6 &, 729 & 7,290 & 86,826 \\
7 &, 507 & 5,070 & 91,896 \\
8 &, 413 & 4,130 & 96,026 \\
9 &, 200 & 1,998 & 98,024 \\
10 &, 121 & 1,209 & 99,233 \\
Extraction Method: Principal Component Analysis. \\
\hline
\end{tabular}

Berdasarkan tabel di atas, diketahui bahwa Eigen values bernilai lebih dari 1 untuk Faktor pengganti 1 dan 2, sedangkan untuk banyaknya faktor pengganti sebanyak 3, eigen value sudah kurang dari 1 (0,905). Oleh karena itu faktor pengganti yang dihasilkan adalah sebanyak 2 faktor.

\section{Pengelompokkan Unsur yang Memiliki Kekerabatan dan Pemberian Nama}

Tahap selanjutnya dalam proses analisis faktor adalah melakukan pengelompokkan terhadap unsur-unsur yang memiliki tingkat kekerabatan yang paling dekat. Untuk keperluan ini, analisis faktor dilakukan di dalam output Rotated Component Matrix yang dihasilkan.

Pengklasifikasian dinyatakan oleh nilai factor loading dengan batas 0,5 atau lebih, dalam hal ini sebuah unsur akan masuk menjadi anggota faktor pengganti jika nilai factor loading lebih besar dari 0,5, tanpa memperhatikan tandanya. Dari hasil analisis dan pemetaan unsur tunggal, masing-masing unsur-unsur $\mathrm{Co}, \mathrm{Ni}, \mathrm{Li}, \mathrm{K}$, $\mathrm{Cr} \mathrm{Zn}, \mathrm{Mn}, \mathrm{Ag}$ dan Fe mempunyai pola sebaran dan batuan yang mendasarinya berupa batupasir, batugamping dan batuan ultrabasa. Analisis korelasi unsur dilakukan untuk mengetahui kekerabatan antar unsur berdasarkan nilai korelasi.

Tabel 5 berikut ini menunjukkan interpretasi bahwa ke-10 unsur dapat diklasifikasikan hanya kepada dua faktor pengganti yang memiliki tingkat kekerabatan unsur lebih tinggi, dalm hal ini Faktor Pengganti pertama terdiri dari unsur $\mathrm{Co}, \mathrm{Ni}, \mathrm{Li}, \mathrm{K}$ dan Cr. Sedangkan Faktor Pengganti kedua berisikan unsur-unsur $\mathrm{Cu}, \mathrm{Zn}, \mathrm{Mn}, \mathrm{Ag}$ dan Fe.

Tabel 5. Rotated Component Matrix dari 4 faktor pengganti

\begin{tabular}{|c|c|c|}
\hline \multirow{2}{*}{ Unsur } & \multicolumn{2}{|c|}{ Faktor Pengganti } \\
\cline { 2 - 3 } & 1 & \multicolumn{1}{|c|}{2} \\
\hline $\mathrm{Cu}$ & 0,519 & $\mathbf{0 , 6 2 8}$ \\
$\mathrm{Zn}$ & 0,283 & $\mathbf{0 , 8 1 6}$ \\
$\mathrm{Co}$ & $\mathbf{- 0 , 7 2 7}$ & 0,390 \\
$\mathrm{Ni}$ & $\mathbf{- 0 , 6 3 1}$ & $-0,115$ \\
$\mathrm{Mn}$ & $-0,365$ & $\mathbf{0 , 7 6 8}$ \\
$\mathrm{Ag}$ & 0,173 & $\mathbf{0 , 5 6 7}$ \\
$\mathrm{Li}$ & $\mathbf{0 , 7 9 8}$ & 0,041 \\
$\mathrm{~K}$ & $\mathbf{0 , 8 6 1}$ & 0,133 \\
$\mathrm{Fe}$ & $-0,173$ & $\mathbf{0 , 9 1 1}$ \\
$\mathrm{Cr}$ & $\mathbf{- 0 , 6 7 4}$ & $-0,056$ \\
\hline
\end{tabular}




\section{POTENSI MINERALISASI LOGAM DASAR}

Secara regional mineralisasi di Weda, Kabupaten Halmahera Tengah adalah mineralisasi nikel laterit. Mineralisasi yang terjadi dalam batuan ultrabasa ditunjukkan oleh adanya mineral garnierit seperti yang ditemukan di sebelah utara Lelilef, Sungai Wasia dan di sebelah barat Gunung Limber dan didukung dengan hasil analisis geokimia ada 5 daerah anomali dengan kandungan (4672ppm - 9600 ppm) terletak pada kawasan komplek batuan ultrabasa (Lampiran peta).

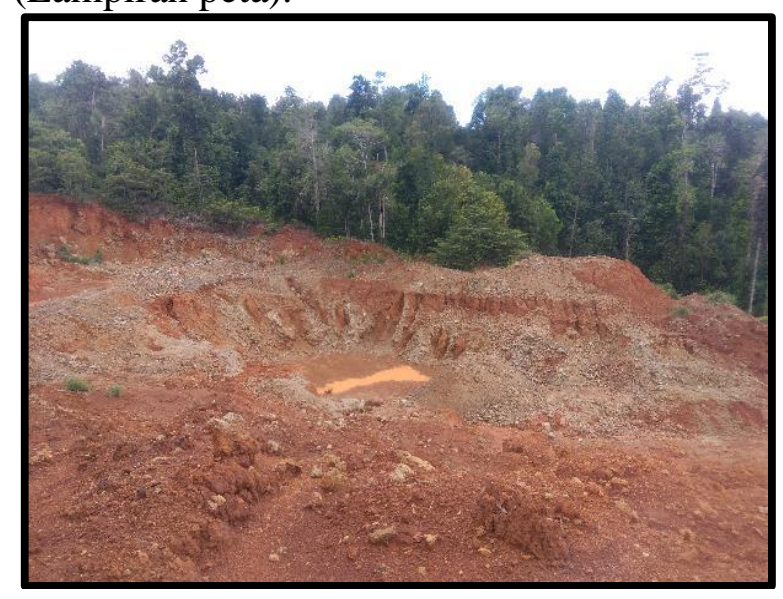

Gambar 7. Endapan nikel laterit

\section{KESIMPULAN}

Hasil analisis dan pemetaan unsur masingmasing unsur mempunyai pola sebaran dan batuan yang mendasarinya berupa batugamping, batupasir dan batuan ultrabasa. Hasil anomali geokimia dengan pola sebaran unsur $\mathrm{Ni}$, di daerah Weda, Kabupaten Halmahera Tengah dapat diketahui melalui metode stream sedimen di lapangan dengan diolah secara statistik dengan diketahui : Unsur Ni (4483.59 9600) ppm,

Analisis korelasi unsur di kawasan penyelidikan terdapat dua asosiasi unsur yang memiliki hubungan berdasarkan data statistik univariat dan multivariat dengan uji analisis faktor. Asosiasi unsur tersebut adalah Faktor 1 : Co,Ni,Li,K,Cr dan Faktor 2 : $\mathrm{Cu}, \mathrm{Zn}, \mathrm{Mn}, \mathrm{Ag}, \mathrm{Fe}$. Indikasi dari pembentukan pada Faktor 1 didapat berdasarkan penggabungan hasil analisis data geokimia yang tercerminkan dari asosiasi unsur di lingkungan permukaan yang diperlihatkan oleh hubungan kuat antara $\mathrm{Ni}$ serta asosiasi $\mathrm{Co}, \mathrm{Li}, \mathrm{K}$ dan $\mathrm{Cr}$ yang dihubungkan dengan kondisi geologi regional daerah penelitian,ditempati oleh banyaknya batuan beku basa dan ultrabasa.

Potensi mineralisasi di daerah penelitian adalah mineralisasi nikel laterit. Mineralisasi yang terjadi dalam batuan ultrabasa ditunjukkan adanya mineral garnierit seperti yang ditemukan si sebelah utara Lelilef, Wasia dan di Yonelo daerah Weda Utara.

\section{DAFTAR PUSTAKA}

Apandi T. dan Sudana D.; 1980. Peta Geologi Lembar Ternate, Skala 1 : 250.000, Pusat Penelitian dan Pengembangan Geologi. Bandung.

Cox, D.P., \& Singer, D.A. 1986. Mineral Deposit Models. U.S Geological Survey Bulletin. No. 1693.

Fadhly,A; 2017. Zonasi Anomali Nilai Unsur Geokimia Di Weda, Kabupaten Halmahera Tengah, Maluku Utara Berdasarkan Data Univariat Dan Multivariat. Bandung.

Faisal, R.M. 2016. Penentuan Zona Anomali Geokimia Sedimen Sungai Untuk Memprediksi Potensi Mineralisasi $\mathrm{Cu}$, $\mathrm{Pb}, \mathrm{Zn}$, di Halmahera Bagian Barat, Maluku Utara. Fakultas Teknik Geologi, Universitas Padjadjaran. Bandung.

Ghazali, S.A, dkk. 1986. Penyelidikan Geokimia Endapan Sungai Metoda dan Teknik, Direktorat Sumberdaya Mineral. Bandung.

Hair, J.F et all. 2010. Multivariate Data Analysis. Seventh Edition. Pearson Prentice Hall 
Kisman, Ernowo, 2007; Inventarisasi Mineral Logam Di Kabupaten Halmahera Timur dan Kabupaten Halmahera Tengah Provinsi Maluku Utara, Proceeding Pemaparan Hasil Kegiatan Lapangan Dan Non Lapangan Tahun 2007 Pusat Sumber Daya Geologi.

Pusat Sumber Daya Geologi. 2014. Panduan Penyelidikan Mineral, Pusat Sumber Daya Geologi. Bandung.

Robert Hall, 1999; Neogen History of Collision in the Halmahera Region, Indonesia. Preceedings, Indoneia Petroleum Association 27 $7^{\text {th }}$ Annual Convention \& Exhibition, October 1999, 487-493.

Sharma, S. 1996. Applied Multivariate Techniques, New-York: John Wiley \& Sons, Inc.

Suprapto, JS. 2013. Geokimia Endapan Sungai Aktif Prospek Mineralisasi Logam Daerah Kabupaten Solok, Sumatera Barat. Fakultas Teknik Geologi, Universitas Padjadjaran. Bandung. 